\title{
Study of thickness of humus profiles of gray forest and chernozem soils of different terms of agricultural use in landscape shrubs of the central forest-steppe
}

\author{
Elena Kovalyova, Ekaterina Kotlyarova, Olga Kuzmina, Yuri Breslavets*, and Alexey \\ Teteryadchenko
}

Belgorod State Agricultural University named after V. Gorin, Mayskiy, Belgorod region, Russia

\begin{abstract}
The article presents the results of a field study of the thickness of the humus profiles of gray forest soils and podzolized chernozems of different terms of agricultural use of soil catens of broad-leaved-forest (background) and meadow-steppe areas of the Belgorod region. The work was carried out in the spring and summer period 2018-2019. The objects of the study were different-aged arable plots with the age of agricultural development of 100 and 160 years, respectively. The steepness of the surface on the plots did not exceed 5-60. It is established that the thickness of humus profile under the influence of agricultural cultivation during 60 years has decreased by $49 \mathrm{~cm}$, at that on the slopes of northern exposition this index is more expressed $(33 \mathrm{~cm})$ than on the slopes of southern exposition $(16 \mathrm{~cm})$. It is possible, to note, that with increase of age of agricultural use on slopes of northern and southern expositions the greatest thickness of humus horizon is observed on anomalous soils ( 72 and 65 sm accordingly). Within the background catens the soil cover is homogeneous, the second humus horizon was observed in each of the studied transects.
\end{abstract}

\section{Introduction}

Morphology of soil profile is quite dynamic and always well reflects peculiarities of soil formation process. The same soil variety, being in different cultural condition for a long time, will have unequal morphological features. The earlier the changes in morphological features are optimized, the better the soils will be preserved [4].

Under the current conditions of increasing intensity of anthropogenic impacts on the components of the natural environment, the degradation of humus, unbalanced removal of nutrients and, as a consequence, a decrease in soil fertility continue in the soils of agricultural landscapes in the forest-steppe zone of the East European Plain [8]. Those types of facies in which the density of compaction is the lowest are the most provided with organic matter [1].

The empirically determined change in the regimes of humus profile formation in chernozems shows the presence of a crisis associated with a decrease in the fixation of humus substances in the soil material in the zone of "insite" humus accumulation and high intensity

\footnotetext{
*Corresponding author: umat_05@mail.ru
} 
of zoogenic mixing, as well as the transition to a slow distribution of humus substances down the profile due to predominantly abiotic processes [3].

In mineral soils, $27-77 \%$ of the organic carbon content is concentrated deeper than the top 0-20 cm layer [10]. According to generalized data including 2073 soil profiles described in various natural zones and ecosystems, the meter thickness of most soils contains 3.1 and 4.3 times more organic $\mathrm{C}$ than at 1-2 and 2-3 m depth, respectively, and the upper $0-20 \mathrm{~cm}$ layer contains from 33 to $50 \%$ of the organic $\mathrm{C}$ contained in the meter layer, depending on the ecosystem type [11].

Studies of the spatial variability of morphogenetic features of forest-steppe chernozems have shown that the stability of the thickness of the humus horizon decreases from watershed to gully slope, which is caused by the complexity of the soil cover and the additional influence of erosion processes [5].

Objective of the study. The aim of the study was a comparative analysis of the structure and properties of soil profiles on background plots with natural vegetation and on arable lands of different terms of agricultural development using the agrochronoradian method.

\section{Materials and research methods}

To select the soil catenaries of the broad-leaved-forest study area, we analyzed historical maps, including: "General Plan of Belogorodsky county" (1785), "Military-Topographic Map of Kursk Province" (1864), V.N. Sukachev's map (1903), on the basis of which the selection of sites with different history of territory development was carried out.

The use of the method of soil agrochronograms was one of the main methods and was based on comparative analysis of the structure and properties of soil profiles on background plots with natural vegetation and on arable lands of different terms of agricultural development. Exposure to slopes (north and south) was also taken into account. Soil samples for analyses were taken within the $2 \mathrm{~m}$ soil profile in every $10 \mathrm{~cm}$ up to a depth of $40 \mathrm{~cm}$ and in every $20 \mathrm{~cm}$ from a depth of $40 \mathrm{~cm}$ up to $200 \mathrm{~cm}$.

As a result of field studies we investigated 41 transects in the broad-leaved-forest key area (13 transects in the background area, 14 transects in each of the ploughed catens of different development age) and 32 transects in the meadow-steppe area (6 transects in the background catens and 12 transects in each of the ploughed catens). A total of 380 soil samples of the Batratskaya Dacha study area were analyzed.

The study area named "Batratskaya Dacha" is located $20 \mathrm{~km}$ from the city of Belgorod, 2 $\mathrm{km}$ south-east of the village of Batratskaya Dacha, Shebekinsky District, Belgorod Region (50³4'20"N; 3647'50"E).

Climate of the study area is predetermined by location in the forest-steppe zone and has a moderate-continental character. Wind speed varies by seasons of the year and varies in the range of $3.8-7.9 \mathrm{~m} / \mathrm{s}$. The average air temperature is $+6.4{ }^{\circ} \mathrm{C}$. The average annual precipitation is $520 \mathrm{~mm}$. The duration with snow cover is 109 days. The duration of the growing season is 197 days. The hydrothermal coefficient is 1.1 .

Plots with 100- and 160-year agricultural development were studied at the distance of 1.5-2 km from the background catens (Fig.1). They represent gully slopes (plots of 100-year arable farming) as well as slopes of the escarpment separating two gullies (plots of 160-year arable farming).

Also, in order to study soil changes under the influence of agricultural cultivation, the background plot under an array of natural broad-leaved forest was investigated. The background forest area represents two catenae that extend down the slopes of the gully of contrasting exposures (south and north). A common transect for the two catenas was plotted at the bottom of the gully. The distance between the studied soil profiles of the background catens was $180-200 \mathrm{~m}$. 


\section{Results and their discussion}

In morphological terms, the soil cover within the background catens of the Batratskaya Dacha plot is homogeneous, all soils belong to the type of gray forest soils and to the subtype of dark gray forest soils; the second humus horizon was observed in each of these transects. Such homogeneity is not observed anywhere in the ploughed areas except for the forest background section of the study.

The profiles of the background soils are distinguished by heterogeneous vertical structure. The profile of these soils includes (Fig.1): A0 forest litter horizon 3-5 cm thick, A1 gray humus horizon with an average thickness of $15-20 \mathrm{~cm}, \mathrm{~A} 1 \mathrm{~A} 2$ transitional humus-alluvial horizon extending to depths of $27-35 \mathrm{~cm}$, with whitish skeletal overlay on the edges of aggregates, A1A2Bth transitional textural-alluvial humus horizon to depths of $35-60 \mathrm{~cm}$, where signs of the second humus horizon are observed eluvial-illuvial texture horizon with signs of the second humus horizon A2Bth - to $56-78 \mathrm{~cm}$, texture subhorizons Bt1, Bt2 and $\mathrm{Bt} 3$ of brown or dark-brown color, extending to the depths of $85-110 \mathrm{~cm}$, which below are replaced by accumulation-carbonate horizons $\mathrm{BCCa}$, transitional to the parent rock.

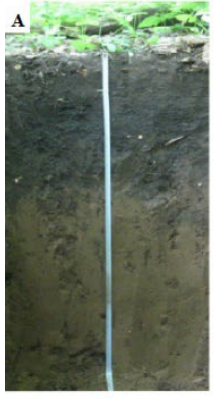

1

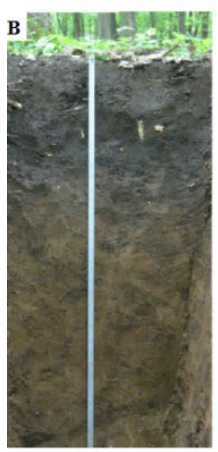

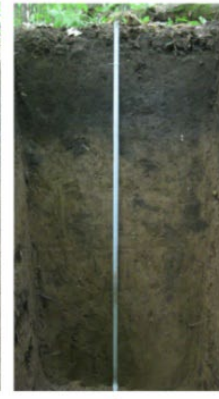

2

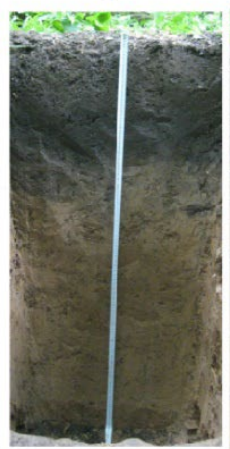

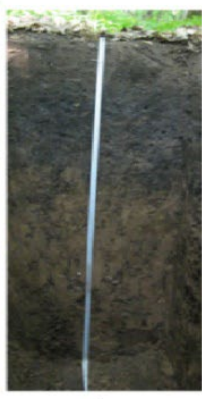

3

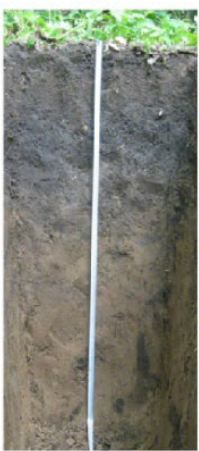

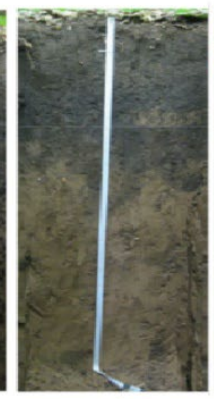

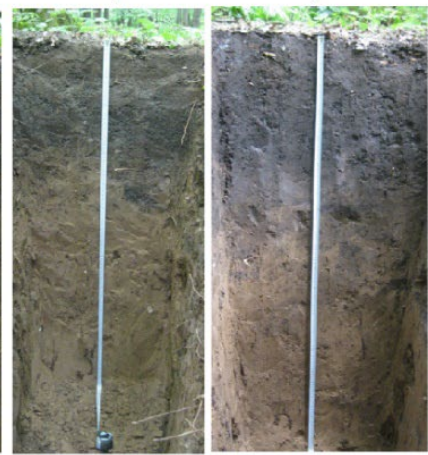

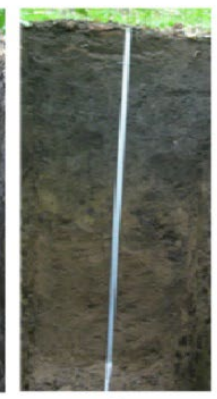

6

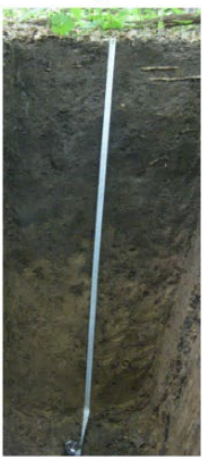

Fig. 1. Cross-sections of the soil catenas of the background area of the northern (A) and southern (B) exposures.

The average thickness of the humus profile (the sum of horizons with index A1 (A1, $\mathrm{A} 1 \mathrm{~A} 2$, etc.)) is $61 \mathrm{~cm}$ in the first two sections of the northern and southern catena, where the slope steepness is completely absent, on both catena. In the sections of the middle part of the catena with a steepness of $2^{0}$, the average thickness of the humus profile in the northern and southern catena is $56 \mathrm{~cm}$ and $67 \mathrm{~cm}$, respectively. The thickness of the humus profile at the bottom of the background catena is $72.5 \mathrm{~cm}$ on the northern slope and $78 \mathrm{~cm}$ on the southern slope.

On the southern exposure catena plot with 100 years of agricultural use (Fig.2), the soils belong to the dark grey forest subtype, but in the lower part of the slope the soils were identified as podzolized chernozems. The ploughed catena of the northern exposure is 
completely represented by podzolized chernozems. These chernozems at this site are agrarian analogues of dark-grey forest soil of the background catena.

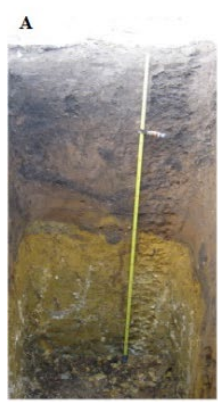

1

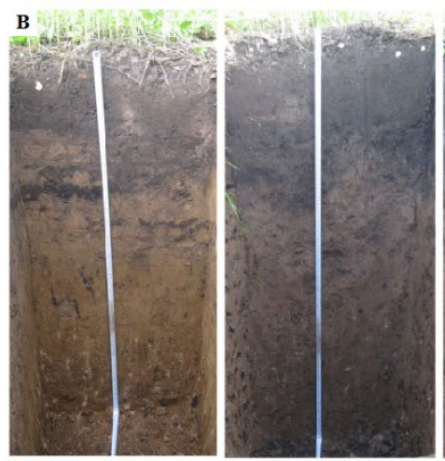

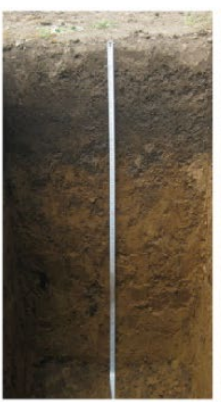

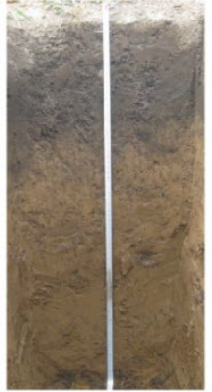

3

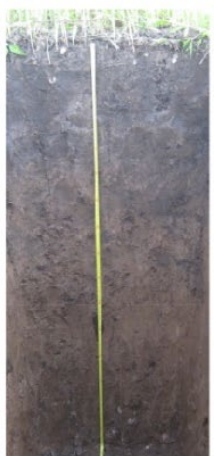

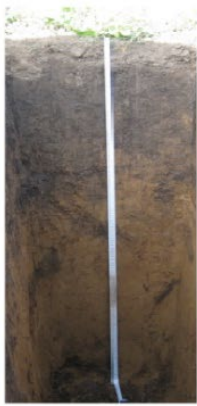

4

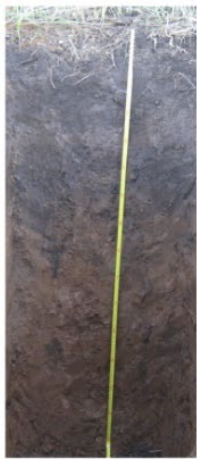

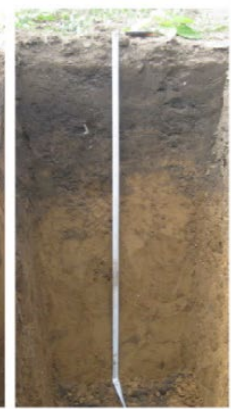

5
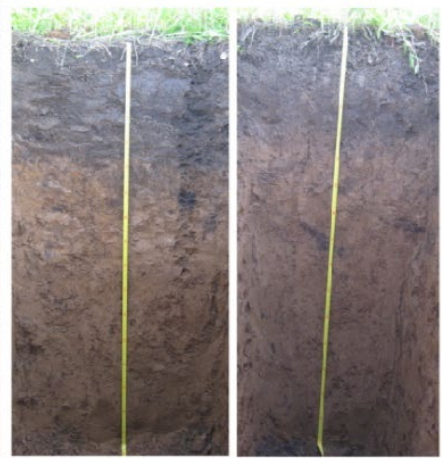

Fig. 2. Cross-sections of the soil catens of the northern (A) and southern (B) exposures with 100 years of ploughing age.

The thickness of the humus profile on the top of a 100-year-old arable land with a steepness of 0-20 years reaches $59 \mathrm{~cm}$ on the slope of northern exposure and $68 \mathrm{~cm}$ on the slope of southern exposure. In the middle of the catena, these values are $54 \mathrm{~cm}$ and $76 \mathrm{~cm}$ respectively. In the lower parts of the rims, these values are $94 \mathrm{~cm}$ and $49 \mathrm{~cm}$, respectively (Fig. 3).

At 160-year agricultural development the thickness of the humus profile on the catena is distributed as follows: $52 \mathrm{~cm}$ on the northern exposure slope and $50 \mathrm{~cm}$ on the southern exposure slope. In the central part of catena these values were $62 \mathrm{~cm}$ each. In the lower parts of the catena this value was $72.5 \mathrm{~cm}$ and $65 \mathrm{~cm}$, respectively. 


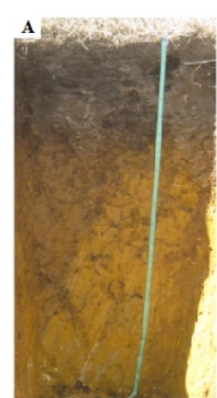

1

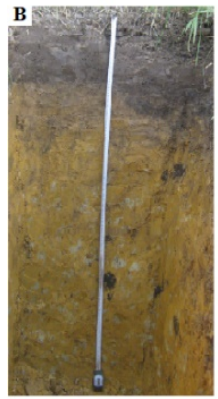

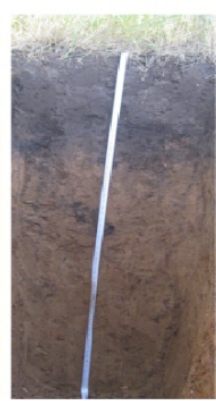

2

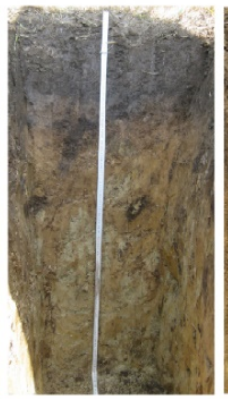

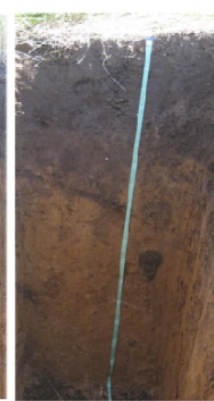

3

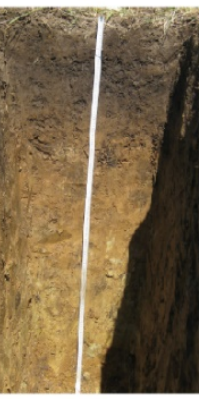

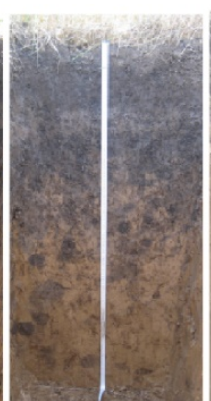

4

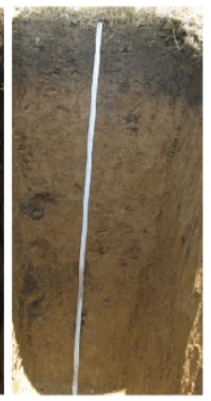

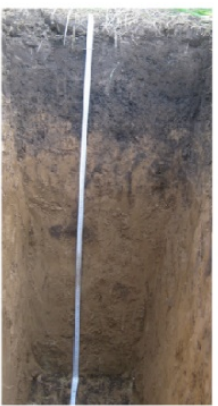

5

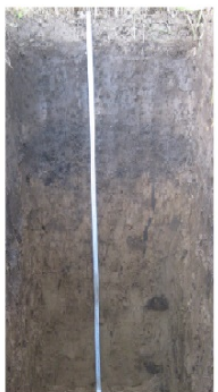

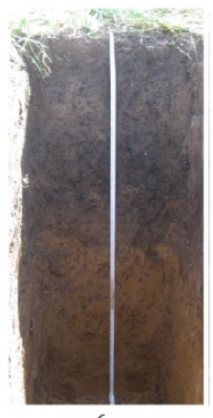

6

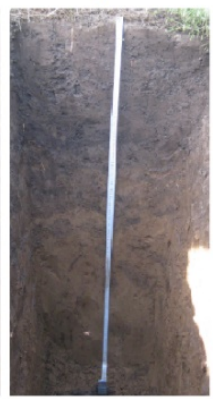

Fig. 3. Cross-sections of the soil catenas of the northern (A) and southern (B) exposures with 160 years of agricultural development.

The content of humus in arable soils has more uniform distribution with depth, and carbonates lie at higher levels and, in general, are characterized by higher content compared to background soils, which is more characteristic of chernozems (Fig. 4,5).

The vertical distribution of humus and carbonates may have been influenced by mole swarming, which mixes different soil layers, which was especially pronounced in the soils of ploughed catens of northern exposition. At the same time, the main reason for the abovementioned evolutionary changes in soils under agricultural use is probably the change of soil climatic regimes [2]. 


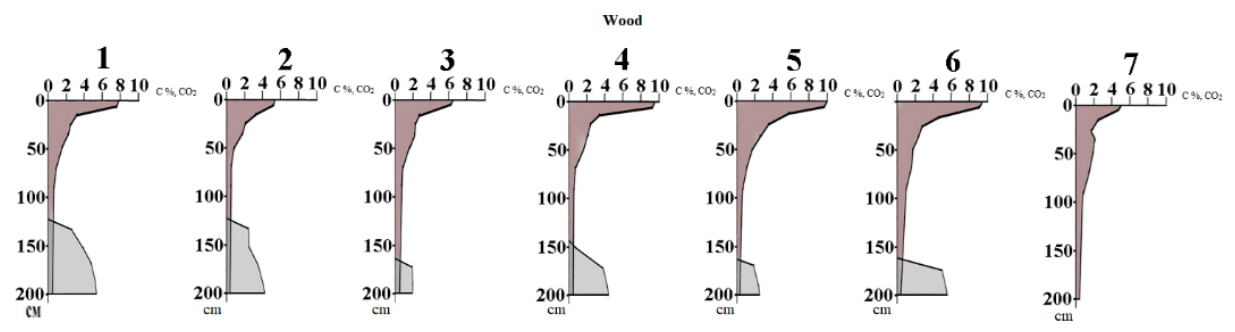

Arable land 100 years
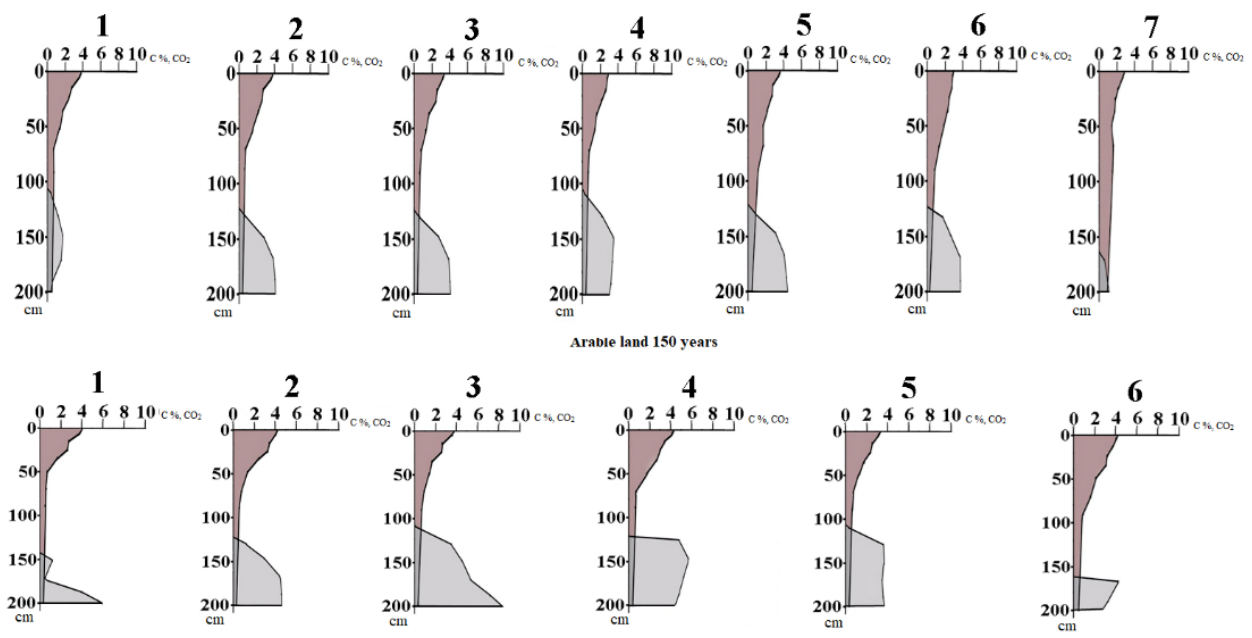

Fig. 4. Distribution of humus and $\mathrm{CO} 2$ carbonate content in soils of the studied catens of northern exposure (Batratskaya Dacha).

In soils under forest the profile distribution of humus has regressive-accumulative character, i.e. in natural gray forest soils there is a sharp decrease of humus with depth. In arable soils, however, the distribution of humus with depth changes to progressiveaccumulative, which is associated with both the emergence of arable horizon, uniformly distributing humus over its thickness, and with a change in the climatic regime of soil formation when forests are replaced by arable land $[6,7]$. 

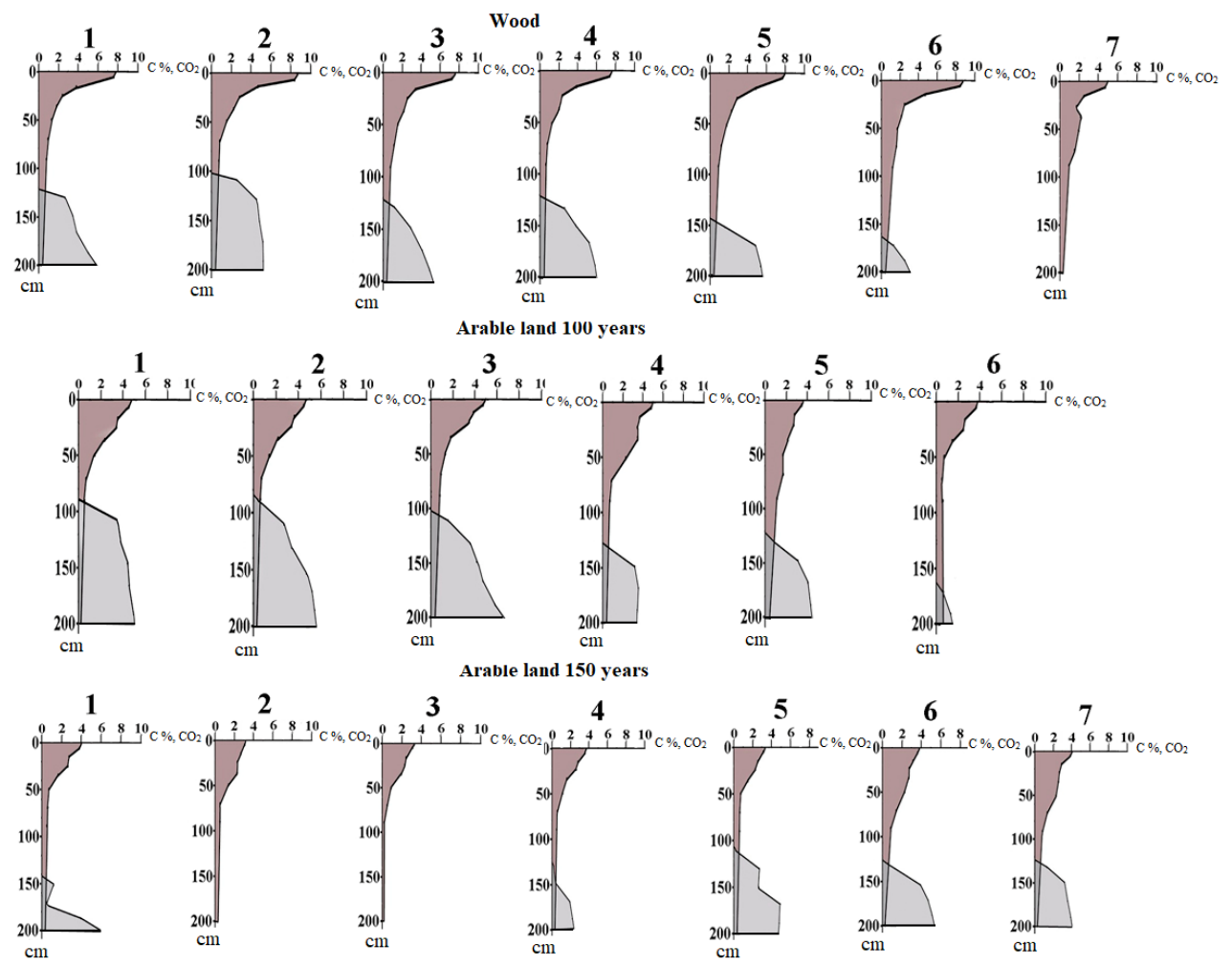

Fig. 5. Distribution of humus and carbonate content in soils of studied shrublands of southern exposure (Batratskaya Dacha).

There is a tendency for improvement of humus condition in subsoil layer, which is associated with the formation of humus accumulation zones (to a depth of $40 \mathrm{~cm}$ ). Similar results were obtained by B.P. Akhtyrtsev and E.V. Efanova (1998) for arable gray forest soils of northern forest-steppe. The authors believe that the accumulation of humus in the subsoil layers of gray forest soils of 70-year development is largely due to the greater root biomass of herbaceous agricultural crops compared to the biomass of grass roots in forest communities. Thus, in the forest in the profile of soils of the middle part of the catena of the northern exposition the content of humus decreases from $10 \%$ to $2-3 \%$ after $20 \mathrm{cmOn}$ an agrarianly developed area the content of humus in the profile of the position analogue of the background soil changes as follows: from 3$4 \%$ at the surface to $1 \%$ at a depth of 1 метр, which indicates the progressive-accumulative nature of humus distribution [9].

\section{Conclusion}

From the analysis we can see that the impact of agricultural tillage did not affect the reduction of the thickness of the humus profile; on transitional and abnormal soils a slight increase in this indicator is revealed. Thus, we detected the so-called "progradation" of dark gray forest soils into chernozems on arable slopes of both exposures.

The general regularity characterizing agrogenic evolution of topogenic conjugations of soils of southern and northern exposition is their degradation into chernozem soils with increasing age of agricultural development. The given process proceeds especially noticeably in soils of catens of northern exposition, which 100-year period of exploitation has already reflected in disappearance of an eluvial part of the soil profiles having horizons with index 
A2 (A1A2, A1A2B, A2B) and their replacement by horizons A1 and A1B of chernozems. In soils of the catena of the southern exposition of the 100 -year period of agricultural use in the upper part of the catena were still identified signs of eluvial horizons of dark-grey forest soils (A1A2, A1A2B, BA2). In soils with age of development of 150 years of northern and southern exposition the above mentioned horizons of eluvial part of soil profiles were already absent, being replaced by horizons A1, A1B, BA1 of chernozems. Only texturally differentiated horizons $\mathrm{Bt}$ with nut-like structure, cutans and illuviation films reminded of the forest past of these soils, immediately below the humus profiles of newly formed agrogenic chernozems. The most significant transformation of morphological features of soils is observed in the lower, most moistened part of slopes, within which the evolutionary transformation of gray forest soils into chernozems takes place at a more intensive rate.

\section{References}

1. I.F. Medvedev [et al.], Agrarnyi nauchnyi zhurnal, 11, 30-34 (2020)

2. Yu.G. Chendev [et al.] Anthropogenic evolution of gray forest-steppe soils of the southern part of the Central Russian Upland 1, 3-15 (2011)

3. P.V. Goleusov, Advances in Modern Natural Science 11-1, 106-110 (2016) URL: http://natural-sciences.ru/ru/article/view?id=36193

4. A.V. Akincin, L.V. Levshakov, S.A. Linkov, V.V. Kim, V.V. Gorbunov, Bulletin of the Kursk State Agricultural Academy 9, 16-21 (2017)

5. Z.M. Azizov, Fertility, 5(86), 42-43 (2015)

6. E.V. Kovaleva, I.Y. Vagurin, A.V. Akinchin, O.S. Kuzmina, Innovations in agroindustrial complex: problems and prospects 1(29), 100-107 (2021)

7. E.V. Kovaleva, I.Y. Vagurin, A.V. Akincin, O.S. Kuzmina, A.I. Teteryadchenko, Agrarnyi nauchnyi zhurnal, 7, 16-20 (2021)

8. E.V. Kovaleva, N.A. Lopachev, I.Y. Vagurin, A.V. Akinchin, O.S.Kuzmina, Innovations in agroindustrial complex: problems and prospects 2(30), 152-161 (2021)

9. E. Kotlyarova, V. Grisina, S. Litsukov, A. Stupakov, E3S web of Conferences, 254, 05006 (2021) https://doi.org/10.1051/e3sconf/202125405006

10. E.G. Kotlyarova, I.A. Kazanbekov, A.I. Titovskaya, IOP Conference Series: Earth and Environmental Science 624, 012228 (2021) doi:10.1088/1755-1315/624/1/012228.

11. E.G. Kotlyarova, A.I. Titovskaia, A.V. Akinchin, M.N. Riazanov, Modern Applied Science 9 (3), 80-90 (2015)

12. S.A. Linkov, A.V. Akincin, I.S. Donchenko, A.A. Popov, News of science in the agroindustrial complex 2-2(11), 16-19 (2018)

13. S.A. Linkov, A.V. Shiryaev, A.V. Akincin, L.N. Kuznetsova, Innovations in the agroindustrial complex: problems and prospects 4(24), 211-219 (2019)

14. I.A. Krupenikov, Soil Science 12, 1509-1517 (2005)

15. Yu.G. Chendev, Achievements of Science and Technology of the Agroindustrial Complex 7 (30), 14-19 (2016)

16. Yu.G. Chendev [et al.], Evolution of forest soil formation in the south of the foreststeppe of the Central Russian Upland in the Late Holocene 1, 3-16 (2017)

17. Y.G. Chendev, Natural changes and anthropogenic transformation of environmental components of the old-developed regions (by the example of the Belgorod Oblast), 124 (Moscow, Moscow State University Press, 2006) 
18. B.P. Akhtyrtsev, E.V. Efanova, Eurasian Soil Science, 31 (7), 729-737 (1998)

19. R.N. Harrison, W.F. Paul, B.D. Strahm, Forest Science, 57, 67-76 (2011)

20. E.G. Jobbagy, R.B. Jackson, Ecological applications 10, 423-436 (2000) 